\title{
MPRA
}

Munich Personal RePEc Archive

\section{THE ANALYSIS OF FIVE COMPETITIVE FORCES OF NON-ALCOHOLIC BEVERAGE INDUSTRY AND E-COMMERCE INDUSTRY CASES AT THE GLOBAL LEVEL}

Manuel, Eduardo

14 April 2007

Online at https://mpra.ub.uni-muenchen.de/3077/

MPRA Paper No. 3077, posted 04 May 2007 UTC 


\title{
THE ANALYSIS OF FIVE COMPETITIVE FORCES OF NON-ALCOHOLIC BEVERAGE INDUSTRY AND E-COMMERCE INDUSTRY CASES AT THE GLOBAL LEVEL
}

\author{
EDUARDO G. MANUEL \\ B.A in Economics and MSc in Management of Enterprises \\ with specialization in Planning and Entrepreneurial Strategy at University Autonoma of \\ Lisbon (UAL), Portugal \\ E-mail address: edu.manuel@economista.com or_eduardo_manuel@mail.pt
}

\begin{abstract}
This paper has as objective to do an analysis of five competitive forces of non-alcoholic industry and e-commerce industry at the global level.

The state of five competitive forces in both industries will depend always of evolution of these industries and government policies of the different countries of the world. For example if these industries are growing and if the govern permit others companies can enter into industry and can help to promote the competition in these industries, that is good for buyers, because they can choose where want to purchase something and what products or goods are according to their necessities or that permits to maximize their utility and it is according to their money amount available for it.
\end{abstract}

Keywords: Industry; Non-alcoholic beverage industry; E-Commerce industry; Five competitive forces

JEL Codes: A23, D29, L19, L29, L69, M19

Working Paper Series 


\section{INTRODUCTION}

We know that there are many kind of the industries engaged in economic activity any where in worldwide.

It is evident that the form and nature of competition is changing within the information economy. Correspondingly, as business respond to the challenges posed by the increased competition associated with the information economy, it is apparent that new sources of competitiveness are emerging (Turner, 2000).

The development of this new business model is derived from changes in the industry structure within which the enterprise is operating, and is needed to secure competitive advantage.

According to Worthington, et al (2005), an industry, is normally defined to the technical and physical characteristics of the output it produces; it comprises all business producing goods within the particular category under investigation, e.g. the brewing industry; the car industry.

For Wheelen and Hunger (2000 and 2006), an industry is a group of firms that produce a similar product or service, such as soft drinks or financial services, and it is a part of their analysis an examination of the important stakeholder groups, such as suppliers and customers, in a particular corporation's task environment).

Whittington, et al (2005) considers that an industry is a group of firms producing the same principal product.

For economists, an industry is a group of firms that supplies a market. And there is a close correspondence between markets and industries (Grant, 2005).

According to Porter (1985), industry structure is determined by five competitive forces (the power of buyers, the power of suppliers, the threat of new entrants, the threat of substitutes and rivalry among suppliers). And it is evident that all of these competitive forces will be affected by the development of the information economy.

This paper has as objective to do an analysis of five competitive forces of nonalcoholic industry and e-commerce industry at the global level.

This work is divided in two points: the first point does a theoretical approach of five competitive forces of industry, and the second point does the analysis of five competitive forces for non-alcoholic beverage industry and e-commerce industry case. 


\section{THEORETICAL APPROACH OF FIVE COMPETITIVE FORCES OF INDUSTRY}

Michael Porter has postulated that the intensity of competition in an industry is determined by its underlying economic structure ${ }^{1}$. And he further contends as we saw above, that the industry structure is shaped by five basic competitive forces: the threat of new entrances into the industry, the bargaining power of suppliers to the industry, the threat of substitute products or services, the bargaining power of customers or buyers, and the Rivalry among Existing Firms (Wheelen and Hunger, 2006) ${ }^{2}$. The figure 1.1 diagrams these competitive forces.

Threats of new entrances
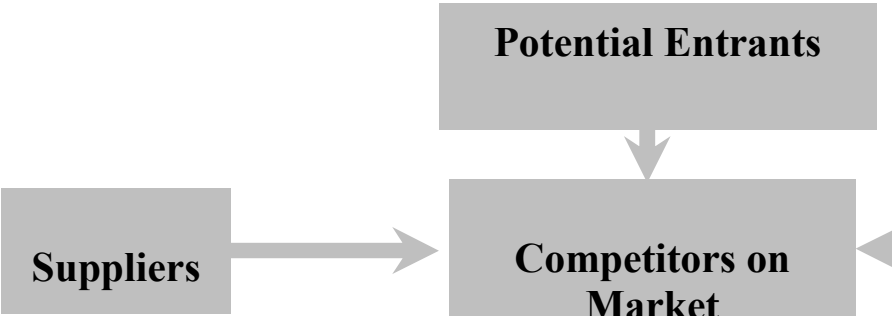

Bargaining Power

of Suppliers

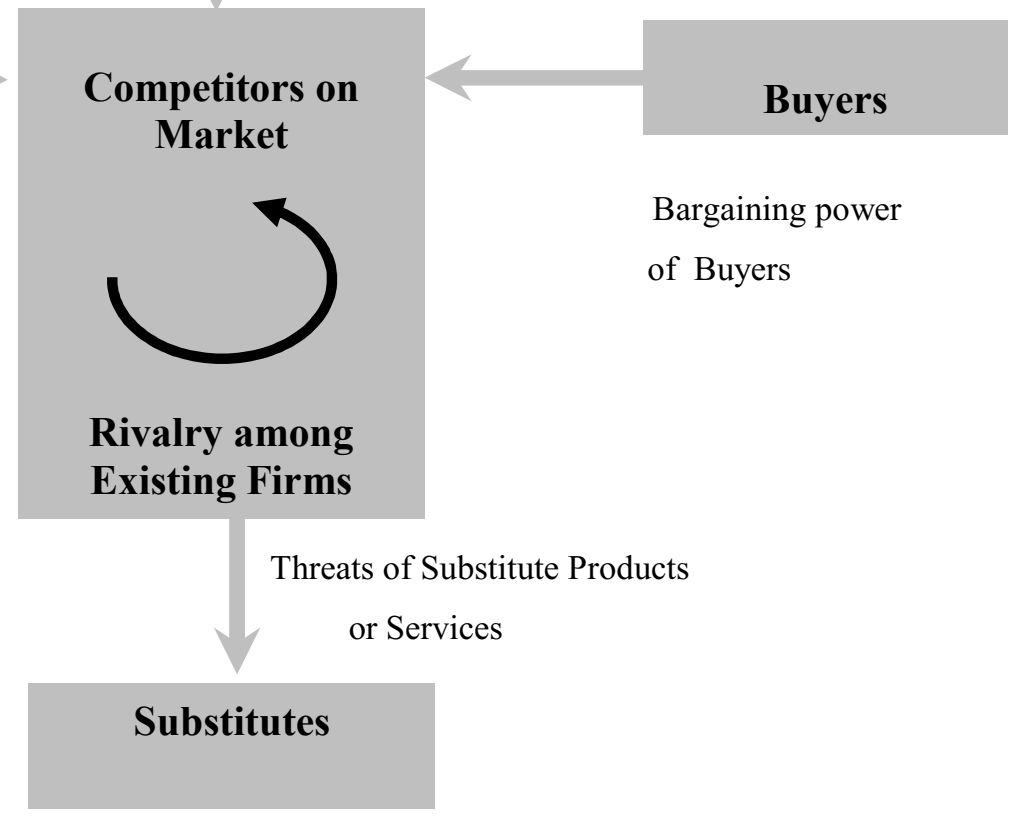

FIGURE 1.1 - Forces Competition in an Industry

Source: Edited by Wheelen and Hunger. 2000; 62 and 2006; 83

\footnotetext{
${ }^{1}$ For further information see PORTER, Michael.1990. The Competitive Advantage of Nations, First Published, Macmillan Press: New York; 34-39.

2 For further information see too THOMPSON, John L.1993. Strategic Management - Awareness and Change, Second edition, Chapman \& Hall: London; 198-207.
} 


\section{Threat of New Entrants}

New entrants to an industry typically bring to it new capacity, a desire to gain market share, and substantial resources. They are threats to an established corporation. The threat of entry depends on the presence of entry barriers and the reaction that can be expected from existing competitors. An entry barrier is an obstruction that makes it difficult for a company to enter an industry. Porter (1985) considers that the possible barriers to entry are:

- Economies of scale;

- Proprietary product differences;

- Brand identity;

- Switching costs;

- Capital requirements;

- Access to distribution;

- Absolute cost advantages (Proprietary learning curve; Access to necessary inputs; Proprietary low-cost product design);

- Government policy;

- Expected retaliation.

\section{Rivalry among existing firms}

According to Wheelen and Hunger (2000), in most industries, corporations are mutually dependent. A competitive move by one firm can be expected to have a noticeable effect on its competitors and thus may cause retaliation or counterefforts.

Porter (1985) defines the following rivalry determinants among existing firms in an industry:

- Industry growth;

- Fixed (or storage) costs/value added;

- Intermittent differences;

- Product differences;

- Brand identity;

- Switching costs; 
- Concentration and balance;

- Informational complexity;

- Diversity of competitors;

- Corporate stakes;

- Exit barriers.

\section{Threat of Substitute Products or Services}

Substitute products are those products that appear to be different but can satisfy the same need as another product. Substitutes limit the potential returns of an industry by placing a ceiling on the prices firms in the industry can profitably charge. To the extent that switching costs are low, substitutes may have a strong effect on an industry.

For Byars (1991), substitute products that deserve the most attention from an organization are those that:

- Have trends improving their price performance trade-off with the industry's product's;

- Are produced by industries earning high profits.

\section{Bargaining Power of Buyers}

Buyers affect an industry through their ability to force down prices, bargain for higher quality or more services, and play competitors against each other (Wheelen and Hunger, 2000 and 2006). A buyer or a group of buyers is powerful if some of the following factors hold true:

- A buyer purchases a large proportion of the seller's product or service, for example, oil filters purchased by a major automaker;

- A buyer has the potential to integrate backward by producing the product itself, for example, a newspaper chain could make its own paper;

- Alternative suppliers are plentiful, because the product is standard or undifferentiated, for example, motorists can choose among many gas stations; 
- Changing suppliers costs very little, for example, office suppliers are easy to find;

- The purchased product represents a high percentage of a buyer's costs, thus providing an incentive to shop around for a lower price, for example, gasoline purchased for resale by convenience stores makes us half their costs;

- A buyer earns low profit and is thus very sensitive to costs and service differences, for example, grocery stores have very small margins;

- The purchased product is unimportant to the final quality or price of a buyer's products or services and thus can be easily substituted without affecting the final product adversely, for example, electric wire bought for use in lamps.

\section{Bargaining Power of Suppliers}

Suppliers can affect and industry through their ability to raise prices or reduce the quality of purchased goods and services.

For Porter (1985), the determinants of supplier powers are the following:

- Differentiation of inputs;

- Switching costs of suppliers and firms in the industry;

- Presence of substitute inputs;

- Supplier concentration;

- Importance of volume to supplier;

- Cost relative to total purchases in the industry;

- Impact of inputs on cost or differentiation;

- Threat of forward integration relative to threat of backward integration by firms in the industry.

Byars (1991) does a short explanation of these determinants according that we saw above and considers that the suppliers are powerful when:

- Their industry is dominated by a few companies and is more concentrated than industry it sells to;

- Their product is unique, differentiated or has built up switching costs; 
- They pose a credible threat of integrating forward;

- Industry is not an important customer of the supplier group.

Wheelen and Hunger (2000 and 2006) refers those that Byars (1991) said and increase that the suppliers are powerful when substitutes firms are not readily available in the industry.

\section{THE ANALYSIS OF FIVE COMPETITIVE FORCES FOR NON-ALCOHOLIC BEVERAGE INDUSTRY AND E-COMMERCE CASE AT THE GLOBAL LEVEL}

\section{Non-alcoholic Beverage Industry case}

In this point I am going to do the analysis of five competitive forces for nonalcoholic beverage industry case, at the global level.

The non-alcoholic beverage industry is characterized by being an industry highly competitive where is numerous firms. These firms include Coca-Cola Company, PepsiCola, Cadbury Schweppes, and others (see annex - table 2.1).

Competitive products beverage that are sold in this industry are concentrates, syrups, soft drink, sport drinks, water, etc, and the table 2.2 (see annex) give us examples of some type of non-alcoholic beverage that are being sold in this industry.

Doing an analysis of five competitive forces for this industry we have that:

\section{1) Threats of entrance of the new enterprises}

Exist entry barriers in the non-alcoholic beverage industry, by fact these market imply highs fix and variable costs the end of activity. Also it depends of governmental 
regulation of countries or regions where the firm is, because for example, the production, distribution and sale are subject to numerous statutes and regulations outside of European Union and United States. All companies are subject to numerous environmental laws and regulations.

\section{2) Rivalry among Existing Firms}

There is rivalry between the existing firms due to universe and to number of competitors. But there is rivalry between the firms for case of products with similar characteristics like Pepsi-cola and Coca-cola, and by fact that the exit barriers are high.

\section{3) Bargaining power of Buyers}

It is strong, because there are many firms in this industry; it is very easy to find other supplier in the industry.

\section{4) Bargaining Power of Suppliers}

It is low, because there are many suppliers in this industry; there is substitute firms in the industry.

But we can say that in case of products supplied for firms with dominant position and that is only viable source for the supply of a product in the market, their bargaining power is strong, and here we can refer the Coca-cola case that purchase acesulfame potassium from Nutrinova Nutrition Specialities \& Food Ingredients $\mathrm{GimbH}$, and that is considered the only viable source by Coca-cola at level of supply of products referred above. 


\section{5) Threats of substitute products or services}

There is threat of substitute products or services, by fact in this industry (Nonalcoholic beverage) are present products in the market that is growing for maturity for case of products like Coca-cola, Fanta, for example.

\section{E-Commerce Industry case}

In this point we are going to do the analysis of five competitive forces for ECommerce Industry at the global level.

E-Commerce or Electronic commerce, according to Wheelen and Hunger (2006), refers to use of the Internet to conduct business transactions.

But it is important here to distinguish the difference between $\boldsymbol{e}$-business and $\boldsymbol{e}$ commerce.

According to Norris, et al (2000), e-commerce focuses on efficiency in selling, marketing, and purchasing, while e-business focuses on effectiveness through improved customer, service, reduced costs and streamlined business process These authors consider that E-business improves business performance by using electronic information technologies and open standards to connect suppliers and customers at all steps along the value chain.

My analysis will be concentrated only in the buying and selling of products in the internet.

In this industry are present the following firms: Amazon.com, Yahoo.com, MSN, eBay, FNAC, and others.

In this industry is being sold products such as DVD's, CD's, PC's, books, phones, mobiles, perfumes, bicycles, furniture, households articles, watch's, academic articles, clothes (for men, woman, and children), etc.

Doing an analysis of five competitive forces for this industry we have that:

\section{1) Threats of entrance of the new enterprises}

There are not significant barriers to entry on industry, because perhaps the firms of the industry have adopted a diversification strategy of sell, the products available to customers are not very differentiated. 


\section{2) Rivalry among Existing Firms}

It is strong; there are divers firms in the industry, such as eBay, Yahoo, MSN, FNAC, etc. This industry is growing, and the products that are being sold are not very differentiated.

\section{3) Bargaining power of Buyers}

It is strong, because it is easy to find other supplier in the industry.

\section{4) Bargaining Power of Suppliers}

In general level, it is low, because the products existing in this industry are sold by many firms.

In case of products like Books, DVD's and CD's the bargaining power of suppliers is low, caused by existence of many suppliers in the Industry.

Firms like Microsoft due to their position in the software product market, we can say that their bargaining power as supplier of firms that sells products like Office, for example is strong, perhaps to have others firms in the industry.

\section{5) Threats of substitute products or services}

In general, it is easy to sell in the internet, so, there are threats of substitute products or service in the e-commerce industry.

There are threat of substitute products, by fact of products sold in the industry could be sold by others firms that are inside or outside of industry, for example, if the buyer do not get satisfied with price of a DVD or Book supplied by Amazon.com, for example, these can choice to buy other product that is being sold by another firm that belongs or not this industry, to a price more low. 


\section{CONCLUSIONS}

In this paper we saw the theoretical approach of five competitive forces as well as the analysis of five competitive forces for non-alcoholic beverage industry and $\boldsymbol{e}$ commerce industry cases at the global level.

We concluded that the state of five competitive forces in both industries will depend always of evolution of these industries and government policies of the different countries of the world. For example if these industries are growing and if the govern permit others companies can enter into industry and can help to promote the competition in these industries, that is good for buyers, because they can choose where want to purchase something and what products or goods are according to their necessities or that permits to maximize their utility and it is according to their money amount available for it. 


\section{REFERENCES}

Beverageworld. 2006. State of the Industry Report 2006, http://www.beverageworld.com/SpecialReports-2006/StateOfIndsty/BW-

StateoftheIndustry-2006.pdf (16 March 2006)

Byars LL.1991. Strategic Management: Formulation and Implementation, Concepts and Cases. Third Edition. HarperCollins Publisher, Inc: New York

Certo SC, Peter JP. 1991. Strategic Management: Concepts and Applications. Second Edition. Mcgraw-Hill International Editions, Management Series: Singapore

Coca-Cola C. 2006. Annual Report 2005, http://www.coca-cola.com (6 May 2006)

Grant RM. 2005. Contemporary Strategy Analysis. Fifth Edition. Blackwell Publisher: Oxford and Victoria

Norris G, et al. 2000. E-Business and ERP-Transforming the Enterprise. John Wiley \& Sons: Canada and United States

PepsiCola. 2007. Annual Report - Performance with purpose, available at http://www.pepsico.com (2 April 2007)

Porter ME. 1985. Competitive Advantage - Creating and Sustaining Superior Performance. The Free Press: New York and Collier Macmillan Publishers: London

Porter M. 1990. The Competitive Advantage of Nations. First Published. Macmillan Press: New York

Thompson JL.1993. Strategic Management - Awareness and Change. Second edition. Chapman \& Hall: London 
THE ANALYSIS OF FIVE COMPETITIVE FORCES FOR NON-ALCOHOLIC INDUSTRY AND E-COMMERCE INDUSTRY CASES AT THE GLOBAL LEVEL

Turner C. 2000. The information e-conomy - business strategies for competing in the global age. First published. Kogan Page Limited: London and Milford

Wheelen TL, Hunger JD. 2000. Strategic Management and Business Policy - Entering $21^{\text {st }}$ Century Global Society. Seventh Edition. Prentice-Hall: New Jersey

Wheelen TL, Hunger JD. 2006. Strategic Management and Business Policy. Tenth Edition. Prentice-Hall: New Jersey

Whittington R, et al. 2005. Exploring Corporate Strategy - Text and Cases, Seventh Edition, Financial Times and Prentice-Hall: London

Whorttington I, et al. 2005. Economics for Business - Blending Theory and Practice. $2^{\text {nd }}$ Edition. Prentice-Hall and Financial Times: London 
THE ANALYSIS OF FIVE COMPETITIVE FORCES FOR NON-ALCOHOLIC INDUSTRY AND E-COMMERCE INDUSTRY CASES AT THE GLOBAL LEVEL

\section{ANNEXES}


THE ANALYSIS OF FIVE COMPETITIVE FORCES FOR NON-ALCOHOLIC INDUSTRY AND E-COMMERCE INDUSTRY CASES AT THE GLOBAL LEVEL

Table 2.1

Some firms that is present in non-alcoholic beverage industry

\begin{tabular}{|c|l|c|}
\hline Rank & \multicolumn{1}{|c|}{ Company } & Market share \\
\hline 1 & $\begin{array}{l}\text { Coca-Cola } \\
\text { Company }\end{array}$ & $43,4 \%$ \\
\hline 2 & Pepsi-Cola & $31,8 \%$ \\
\hline 3 & Cadbury Schweppes & $14,7 \%$ \\
\hline 4 & Cott Corporation & $5,4 \%$ \\
\hline 5 & National & $2,4 \%$ \\
\hline 6 & Big Red & $0,3 \%$ \\
\hline 7 & Monarch & $0,1 \%$ \\
\hline 8 & Carolina Beverage & $0,1 \%$ \\
\hline \multirow{2}{*}{} & Leading & $\mathbf{9 8 , 1 \%}$ \\
\cline { 2 - 3 } & Companies & \\
\hline
\end{tabular}

Source: BeverageWorld. 2006 
THE ANALYSIS OF FIVE COMPETITIVE FORCES FOR NON-ALCOHOLIC INDUSTRY AND E-COMMERCE INDUSTRY CASES AT THE GLOBAL LEVEL

Table 2.2

Some products that is sold in non-alcoholic beverage industry

\begin{tabular}{|c|c|c|}
\hline Rank & Company & Market share \\
\hline 1 & Coca-Cola Classic & $17,7 \%$ \\
\hline 2 & Pepsi-Cola & $11,8 \%$ \\
\hline 3 & Diet Coke & $9,9 \%$ \\
\hline 4 & Mountain Dew & $6,6 \%$ \\
\hline 5 & Diet Pepsi & $5,8 \%$ \\
\hline 6 & Sprite & $5,7 \%$ \\
\hline 7 & Dr Pepper & $5,7 \%$ \\
\hline 8 & $\begin{array}{l}\text { Caffeine Free Diet } \\
\text { Coke }\end{array}$ & $1,6 \%$ \\
\hline 9 & Fanta & $1,4 \%$ \\
\hline \multirow[t]{2}{*}{10} & Sierra Mist & $1,4 \%$ \\
\hline & Total Industry & - \\
\hline
\end{tabular}

Source: BeverageWorld. 2006 